\title{
Model of Long-Term Vitamin A Deficiency in the Mammary Gland of Virgin Rats
}

\author{
Miriam Ester Vasquez Gomez, Silvia Varas, Maria Sofia Gimenez \\ Department of Biochemistry and Biological Sciences, Faculty of Chemistry, Biochemistry and Pharmacy, National University of \\ San Luis, San Luis, Argentina \\ Email: eridnere@gmail.com,mgimenez@unsl.edu.ar
}

How to cite this paper: Gomez, M.E.V., Varas, S. and Gimenez, M.S. (2017) Model of Long-Term Vitamin A Deficiency in the Mammary Gland of Virgin Rats. Open Access Library Journal, 4: e3887. https://doi.org/10.4236/oalib.1103887

Received: August 15, 2017

Accepted: September 15, 2017

Published: September 18, 2017

Copyright (c 2017 by authors and Open Access Library Inc.

This work is licensed under the Creative Commons Attribution International License (CC BY 4.0).

http://creativecommons.org/licenses/by/4.0/ c) (i) Open Access

\begin{abstract}
Deficiency in vitamin A is an evil in underdeveloped countries where the minimum recommended intake is not achieved. This may have long-term implications on the health of the population. For this reason, it would be very useful to achieve an animal model where the different implications of this deficiency can be observed. This could lead to the formulation of future nutrition politics. The levels of retinoic acid and intermediary of the vitamin A pathway were studied; The levels of retinoic acid and intermediary of the vitamin A pathway (CRBP-1 and RAR $\alpha$ ) were studied. There was a decrease in the values of retinoic acid main indicator of deficiency of this vitamin in serum, liver and mammary gland and variation in expression of CRBP-1 and RAR $\alpha$ mRNA in mammary gland. This model provides a tool for the study of the metabolism of vitamin A and its effects in different organs and especially in virgin mammary gland, where a deficiency is achieved despite being in a state of latency.
\end{abstract}

\section{Subject Areas}

Nutrition

\section{Keywords}

Retinoic Acid, Nutrition, CRBP-1, RAR $\alpha$

\section{Introduction}

Worldwide, vitamin A deficiency (VAD) affects an estimated of 190 million preschool-aged children and 19.1 million pregnant women [1]. It has been estimated that $44.4 \%$ of pre-school children in Africa would be at risk of VAD [2]. In Ethiopia, this deficiency leads to 80,000 deaths per year and affects $61 \%$ of 
pre-school children [3]. Vitamin A deficiency remains a widespread public health problem among women and children in the developing world [4], and it increases morbidity and mortality due to increased susceptibility to infection [5].

Vitamin A and its derivatives (referred to as retinoids) are essential dietary compounds and are key regulators of cell differentiation, proliferation, and death. It is estimated that more than 500 genes are regulated by retinoic acid [6], through the binding and activation of the different isoforms of retinoic acid receptors (RAR $\alpha, \beta$ and $\gamma$ ) and retinoid X receptors (RXR), which are members of the nuclear receptor family. Adult animals deprived of vitamin A display severe abnormalities including dysfunction of epithelia of mammary gland [7] [8].

The nutritional requirements of vitamin A have been calculated through studies in which attempts have been made to correct experimentally produced deficiency states. Current recommendations from the Food and Nutrition Board of the National Research Council are based on the amount of retinoids needed to cover variations between absorption and utilization. VAD is recognized as a nutritional problem in many countries. VAD is considered to affect growth only under severe deficit conditions of $(0.7 \mu \mathrm{mol} / \mathrm{l})$ [9] [10] [11] [12]. In fasting circulation, retinol (the predominant vitamin A species) bound to RBP (Retinol Binding Protein) is found at a normal concentration ranging from 2 to $4 \mu \mathrm{M}$ in humans and about $1 \mu \mathrm{M}$ in rodents [13].

The study of the effects of marginal vitamin A deficiency is of great importance as it reflects situation of many human beings, particularly those in developing countries. For this reason, an animal model of deficiency should be used to study the metabolic changes.

\section{Materials and Methods}

\section{Animals and Diets}

Wistar rats are a good model for nutritional studies. Female Wistar rats, bred in our animal facilities (IMIBIO, National University of San Luis, Argentina), were weaned at 21 days old and immediately randomly assigned to either the experimental group (standard diet, devoid of vitamin A [VAD group]), the control (CO) group (standard diet with 4000 IU of vitamin A [8 mg retinol as retinyl palmitate] per kilogram of diet) or refed group (REF). The experimental period was 6 months for VAD and $\mathrm{CO}$ and 5 months with VAD diet and 30 days with control diet for the REF group. REF group was used to study the reversibility of the possible changes caused by the vitamin deficiency. Diets, mineral mix and vitamin mix were prepared according to the AIN-93 for laboratory rodents [14]. The composition (grams per kilogram diet) of experimental and $\mathrm{CO}$ diets are shown in Tables 1-3. The rats were kept in a $21^{\circ} \mathrm{C}-23^{\circ} \mathrm{C}$ controlled environment with a 12-hour light:dark cycle. They were given free access to food and water throughout the entire experimental period. After the entire treatment period, 4 rats from each group (CO, VAD and REF) were euthanized by $\mathrm{CO}_{2}$ inhalation. The blood was collected without anticoagulant in order to obtain the se- 
rum. For this purpose, the samples were washed with $\mathrm{H}_{2} \mathrm{O}$ at $37^{\circ} \mathrm{C}$ for $20 \mathrm{~min}$. The serum was then centrifuged 2 times at $3000 \mathrm{rpm}$ for $10 \mathrm{~min}$. Then the inguinal mammary gland and liver were separated. The tissue fractions were maintained at $-70^{\circ} \mathrm{C}$. The samples for the determination of retinol were separated and protected from light, in order to decrease the photoisomerization of vitamin $\mathrm{A}$. We followed the general guidelines for the care and use of laboratory animals recommended by the Animal Care Committee of the National University of San Luis.

\section{Retinol Concentration Analyses}

The retinol concentration was determined by the modified technique Neeld and

Table 1. Ingredient composition of the diet fed to rats.

\begin{tabular}{cc}
\hline Ingredients & g/kg diet \\
\hline Corn starch & 397.5 \\
Sucrose & 100 \\
Dextrinized corn starch & 132 \\
Lactalbumin & 200 \\
Soybean oil & 70 \\
Cellulose fiber & 50 \\
AIN-93 mineral mix & 35 \\
AIN-93 vitamin mix & 10 \\
L-cystine & 3 \\
Choline bitartrate & 2.5 \\
Tert-butylhydroquinone & 0.0014 \\
\hline
\end{tabular}

Table 2. AIN-93 vitamin mix.

\begin{tabular}{ccc}
\hline Vitamin & g/kg diet (CO) & g/kg diet (VAD) \\
\hline Nicotinic acid & 3.000 & 3.000 \\
Calcium Pantothenate & 1.600 & 1.600 \\
Pyridoxine-HCl & 0.700 & 0.700 \\
Thiamine-HCl & 0.600 & 0.600 \\
Riboflavin & 0.600 & 0.600 \\
Folic acid & 0.200 & 0.200 \\
D- Biotin & 0.020 & 0.020 \\
Vitamin B-12 (cianocobalamina) & 2.500 & 2.500 \\
Vitamin E (500 UI/g) & 15.000 & 15.000 \\
Vitamin A (trans-retinilpalmitato) & 0.800 & - \\
Vitamin D3 (400.000 UI/g) & 0.250 & 0.250 \\
Vitamin K & 0.075 & 0.075 \\
Sucrose & 974.655 & 975.455 \\
\hline
\end{tabular}


Table 3. AIN-93 mineral mix.

\begin{tabular}{|c|c|}
\hline Minerals & $\mathrm{mg} / \mathrm{kg}$ diet \\
\hline \multicolumn{2}{|l|}{ a) Essential mineral elements: } \\
\hline Calcium carbonate, anhydrous & 357.00 \\
\hline Potassium phosphate, monobasic & 196.00 \\
\hline Potassium citrate, monohydrate & 70.78 \\
\hline Sodium chloride & 74.00 \\
\hline Potassium sulfate & 46.60 \\
\hline Magnesium oxide & 24.00 \\
\hline Ferric citrate & 6.06 \\
\hline Zinc carbonate & 1.65 \\
\hline Manganese carbonate & 0.63 \\
\hline Cupric carbonate & 0.30 \\
\hline Potassium iodide & 0.01 \\
\hline Sodium selenate, anhydrous & 0.01025 \\
\hline Ammonium Paramolybdate. $4 \mathrm{H}_{2} \mathrm{O}$ & 0.00795 \\
\hline \multicolumn{2}{|l|}{ b) Potentially beneficial elements: } \\
\hline Sodium metasilicate. $9 \mathrm{H}_{2} \mathrm{O}$ & 1.4500 \\
\hline Chromium and potassium sulphate. $12 \mathrm{H}_{2} \mathrm{O}$ & 0.2750 \\
\hline Lithium chloride & 0.0174 \\
\hline Boric acid & 0.0815 \\
\hline Sodium Fluoride & 0.0635 \\
\hline Nickel carbonate & 0.0318 \\
\hline Ammonium Vanadate & 0.0066 \\
\hline Sucrose & 221.0260 \\
\hline
\end{tabular}

Pearson [15]. The homogenates of liver or mammary gland and serum, was treated with $1 \mathrm{ml}$ of $95 \%$ ethanol to precipitate proteins, and $1.5 \mathrm{ml}$ of petroleum ether to extract vitamin A and carotenoids. It was centrifuged at $3000 \mathrm{rpm}$ for 10 minutes at $37^{\circ} \mathrm{C}$. The supernatant was read at $450 \mathrm{~nm}$, corresponding to the absorbance of carotenes. Then was dried in an oven at $37^{\circ} \mathrm{C}$ and the residue was taken up in $50 \mu \mathrm{l}$ of chloroform, $50 \mu \mathrm{l}$ of acetic anhydride and $500 \mu \mathrm{l}$ of TFA (Trifluoroacetic) is then added with vigorous stirring to $620 \mathrm{~nm}$ absorbance (OD620) and read within 30 seconds. In parallel a standard curve of vitamin A and carotenes process was made. Because the $\beta$-carotene reacts with TFA, the results were corrected after reading the absorbance at $450 \mathrm{~nm}$ and calculate the corresponding correction factor. All measurements were performed in duplicate.

\section{RNA Isolation and RT-PCR Analysis}

Total RNA was isolated from 150/200 mg of mammary tissue using the guanidi- 
nium isothiocyanate-acid phenol method as modified by Puissant and Houdebine [16]. Ten micrograms of total RNA were reverse transcribed (RT) at $37^{\circ} \mathrm{C}$ using random hexamer primers and Moloney murine leukemia virus retrotranscriptase (Invitrogen-Life Technologies, Buenos Aires, Argentina) in a $20 \mu \mathrm{L}$ reaction mixture. The RNA was first denatured at $70^{\circ} \mathrm{C}$ for $5 \mathrm{~min}$ in the presence of $2.5 \mu \mathrm{g}$ of random hexamer primers (Invitrogen). For the subsequent RT reaction the following mixture was added: RT buffer [50 mM TriseHCl (pH8.4), 75 $\mathrm{mM} \mathrm{KCl}, 3 \mathrm{mM} \mathrm{MgCl}_{2}$ ], $0.5 \mathrm{mM}$ dNTPs, $5 \mathrm{mM} \mathrm{DTT}, 200$ units M-MLV Reverse Transcriptase. The reaction was incubated at $37^{\circ} \mathrm{C}$ for $50 \mathrm{~min}$, and then the reaction was inactivated by heating at $70^{\circ} \mathrm{C}$ during $15 \mathrm{~min}$. The $\mathrm{cDNA}$ was stored at $20^{\circ} \mathrm{C}$. The mRNA levels of CRBP-1, RAR $\alpha$ and S28 were estimated by RT-PCR using rat-specific primers and reaction conditions described in Table 4. The PCR reactions were performed using a Biorad Thermocycler in a final volume of $20 \mu \mathrm{L}$. The reaction mixture consisted of $2 \mu \mathrm{L}$ of 10X PCR Buffer, $1 \mu \mathrm{L}$ of $50 \mathrm{mM}$ $\mathrm{MgCl}_{2}, 0.4 \mu \mathrm{L}$ of $10 \mathrm{mM}$ dNTP Mix (Invitrogen), $0.25 \mu \mathrm{L}$ of $5 \mathrm{U} / \mathrm{mL}$ Taq DNA Polymerase (Invitrogen), $0.1 \mu \mathrm{L}$ of each $2.5 \mathrm{mM}$ primer (forward and reverse primers) and $11 \mu \mathrm{L}$ of diluted cDNA. The PCR reactions were initiated with 5 min incubation at $95^{\circ} \mathrm{C}$, followed by 40 cycles of $95^{\circ} \mathrm{C}$ for $60 \mathrm{~s}, 60 \mathrm{~s}$ at the annealing temperatures shown in Table 4 and $72^{\circ} \mathrm{C}$ for $60 \mathrm{~s}$. Each PCR run included a notemplate control and a sample without RT. All measurements were performed in duplicate. RNA samples were assayed for DNA contamination by performing the different PCR reactions without prior RT. Relative levels of mRNA were normalized to the S28 reference gene. The resultant products obtained after PCR were separated by electrophoresis on $2 \%$ agarose gel containing GelRed. The image was visualized and photographed under UV transillumination.

\section{Statistical Analysis}

Results were expressed as mean values with their standard device. Statistical comparisons were made transversely between different dietary groups. The statistical significance between groups was determined by one-way ANOVA and the differences between the individual means were analyzed using Tukey's post hoc test. Differences having P values lower than 0.05 were considered to be statistically significant. Data analysis was done using the Graphpad prism 5 software. The images were taken with digital camera and the images analyzed with Image J software.

Table 4. PCR primers and conditions.

\begin{tabular}{|c|c|c|c|c|c|}
\hline Gene & Primer sense $\left(5^{\prime}-3^{\prime}\right)$ & Primer Antisense ( $\left.5^{\prime}-3^{\prime}\right)$ & $\operatorname{Tm}\left({ }^{\circ} \mathrm{C}\right)$ & Amplicon size & Gene Bank Accessions \\
\hline CRBP-1 & ACGTGGCCTTGCGAAAAATC & TCATGCACTTGCGGTCATCT & 58 & $174 \mathrm{bp}$ & NM 012733.4 \\
\hline $\operatorname{RAR} \alpha$ & CGCCTGTGAGGGCTGTAAG & ATGCCCACTTCGAAGCATTT & 61 & $150 \mathrm{bp}$ & NM_031528 \\
\hline S28 & GTGAAAGCGGGGCCTCACGATCC & GTACTGAGCAGGATTACCATGGC & 59 & $289 \mathrm{bp}$ & NR 046239.1 \\
\hline
\end{tabular}




\section{Results}

\subsection{Body Weight}

When analyzing the animal weights, a significant decrease was observed in the experimental groups with VAD diet, from week 8 on diet intake, regarding the respective CO group (data not shown). It is noteworthy that the animals belonging to REF group had a weight gain equivalent to the CO group (Table 5). No differences were observed in the daily intake between the different experimental lots.

\subsection{Retinoic Acid Levels}

The content of retinoic acid in serum, liver and mammary gland was measured (Table 6). The dietary restriction of vitamin A for 24 weeks caused a decrease in retinoic acid levels in serum, liver and mammary gland with respect to $\mathrm{CO}$ group; indicating a specific state of nutritional deficiency of vitamin A. This state was reversed in serum, in liver and mammary gland with feedback of 4 weeks.

\subsection{Effect of VAD on CRBP-1 mRNA expression}

The expression of CRBP-1 in mammary gland was determined. Figure 1 shows the expression of CRBP-1 in mammary gland in the different experimental groups, where a decrease in expression is observed both in the group with deprived diet of vitamin A (VAD group) and in those subsequently supplemented (REF group).

\subsection{Effect of VAD on RAR $\alpha$ mRNA Expression}

Expression of RAR $\alpha$ was determined. Figure 2 shows RAR $\alpha$ expression in mammary gland in the different experimental groups, where a decrease in

Table 5. Weights of the different experimental groups.

\begin{tabular}{cccc}
\hline & CO & VAD & REF \\
\hline Initial weight (g) & $60.75 \pm 4.85$ & $54.50 \pm 6.45$ & $52.75 \pm 5.79$ \\
Final weight (g) & $341.5 \pm 2.88^{\mathrm{c}}$ & $296.3 \pm 16.76^{\mathrm{d}}$ & $318.5 \pm 9.14^{\mathrm{e}}$ \\
Weight Gain (g) & $280.8 \pm 2.22^{\mathrm{c}}$ & $241.8 \pm 1.15^{\mathrm{d}}$ & $264.5 \pm 5.68^{\mathrm{c}}$ \\
\hline
\end{tabular}

Values are expressed as the mean $\pm S D(n=8)$. Medias with a different letter are statistically significant $(\mathrm{p}<$ $0.05)$.

Table 6. Retinoic acid levels in serum, liver and mammary gland.

\begin{tabular}{cccc}
\hline & CO & VAD & REF \\
\hline Serum $(\mu \mathrm{mol} / \mathrm{l})$ & $1.79 \pm 0.32^{\mathrm{b}}$ & $0.06 \pm 0.027^{\mathrm{d}}$ & $1.92 \pm 0.27^{\mathrm{b}}$ \\
Liver $(\mu \mathrm{mol} / \mathrm{g})$ & $1.71 \pm 0.20^{\mathrm{b}}$ & $0.08 \pm 0.03^{\mathrm{a}}$ & $1.51 \pm 0.06^{\mathrm{b}}$ \\
Mammary gland $(\mu \mathrm{mol} / \mathrm{g})$ & $0.95 \pm 0.04^{\mathrm{b}}$ & $0.11 \pm 0.08^{\mathrm{a}}$ & $0.36 \pm 0.03^{\mathrm{c}}$ \\
\hline
\end{tabular}

Values are expressed as the mean \pm SD $(n=4)$. Medias with a different letter are statistically significant $(\mathrm{p}<$ $0.05)$. 


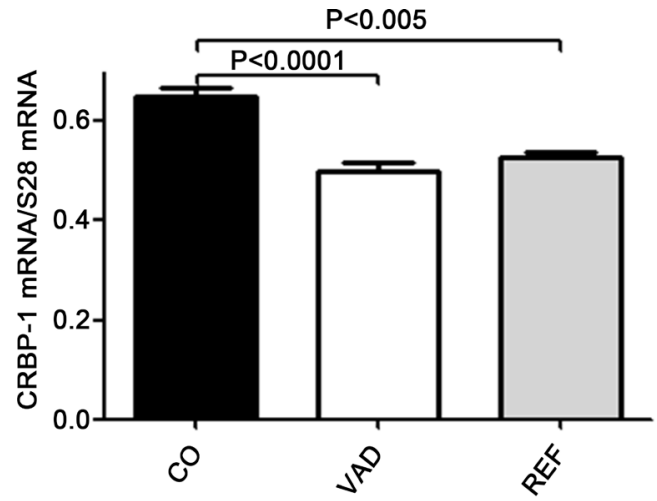

(a)

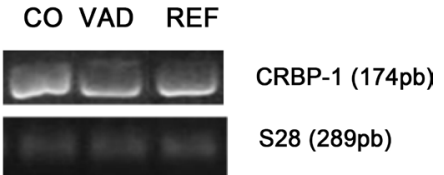

(b)

Figure 1. Expression of CRBP-1 in mammary gland by RT-PCR in the different experimental groups. (a) Semi-quantitative analysis of CRBP-1 expression. (b) Gel representative of the gene expression of CRBP-1 in the different experimental groups. Expression of CRBP-1 was performed using specific primers, and was adjusted for expression of the constitutive gene S28, as described in Materials and Methods. Representative image of agarose gel for CRBP-1 (174 pb) and S28 (284 bp) products.

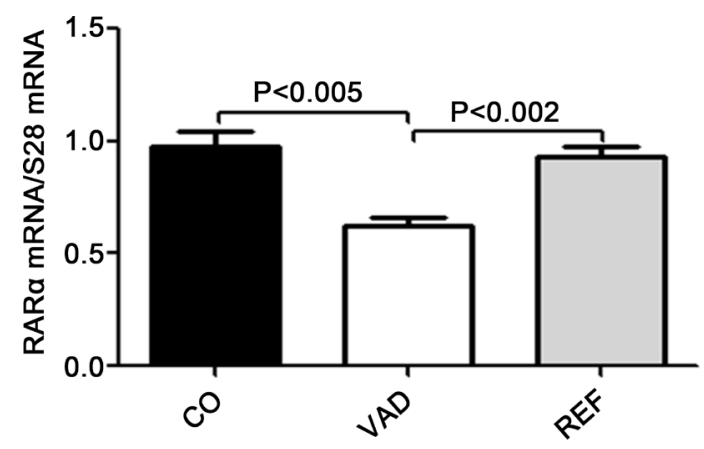

(a)

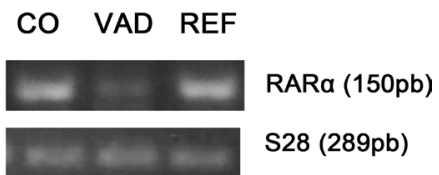

(b)

Figure 2. Expression of RAR $\alpha$ in mammary gland by RT-PCR in the different experimental groups. (a) Semi-quantitative analysis of RAR $\alpha$ expression. (b) Gel representative of the gene expression of RAR $\alpha$ in the different experimental groups. Expression of RAR $\alpha$ was performed using specific primers, and was adjusted for expression of the constitutive gene S28, as described in Materials and Methods. Representative image of agarose gel for RAR $\alpha(150 \mathrm{pb})$ and S28 (284 bp) products.

expression in the VAD group and an increase after supplementation was observed. The 30-day diet with enough vitamin A diet was sufficient for the REF group to return to the control values.

\section{Discussion}

In the present study, a model of long-term deficiency is proposed for the study of the changes caused by the prolonged absence of vitamin A in virgin mammary gland.

In this model, a significant decrease in body weight gain was observed in VAD group. VAD is considered to affect growth only under conditions of severe deficit $(<0.7 \mu \mathrm{mol} / \mathrm{l})$ [9] [11] [12]. In rodents, the normal concentration of retinol is of the $1 \mu \mathrm{M}$ [13]. Vitamin A is an essential nutrient for mammalian growth and a 
decrease in body weight gain and alterations in anthropometric measures has been observed in children with subclinical and clinical deficits [17].

In rodents, disturbances of vitamin A signaling, due to dietary depletion or genetic manipulation, may promote deregulation of adipose tissue [18]. Treatment of rodents with vitamin A or retinoic acid can change the expression levels of adipose genes involved in energy homeostasis [19].

In our model, dietary intake without vitamin A causes alterations in the amount of retinoic acid in serum, in liver (which is the reserve organ for vitamin A [20] [21], and in mammary gland. Our results demonstrate that levels of circulating retinoic acid decreased compared with the CO group. During the refed period, we could observe that the values of retinoic acid reached the values of the $\mathrm{CO}$ group. In liver and mammary gland of the VAD group, we observed that these levels were lower compared to the $\mathrm{CO}$ group. In liver, during the refed period, we could observe that the values of retinoic acid reached the values of the CO group. In mammary gland, the levels of retinoic acid observed increased with respect to the VAD group.

According to a study conducted by Ross [22], rats fed with a deprived diet of vitamin A showed retinoic acid deficiency in liver $(<5 \mathrm{mg} / \mathrm{g}$ tissue) and plasma $(<0.3 \mathrm{M})$ at 7 weeks age in males and 8 weeks of age in females. Moreover, external signs of vitamin A deficiency were manifested approximately one week later for both sexes [22]. These findings are consistent with our findings; where at 8 weeks in the VAD group the signs of Vitamin A deficiency were observed.

It has been shown that retinoic acid regulates cellular processes including cell proliferation, differentiation and apoptosis, and therefore plays important roles in embryo development and subsequent tissue maintenance [23] [24] [25]. Retinoic acid signaling is involved in the initiation of mammary gland development in the embryonic stage [26]. The RARs are the main mediators of the biological effects of vitamin A, with an established role in the maintenance of differentiated state of epithelial tissues [27]. In turn, the RAR signaling pathway has been shown to be defective in carcinomas of various organs, such as the mammary gland, mainly because of reduced expression of RAR $\beta$ or CRBP-1 [28] [29]. However, if these alterations affect the oncogenesis or maintenance of the tumor, it still remains unresolved. It has been reported that nutritional status in vitamin A would alter the expression of the different RAR subtypes in tissues [30] [31] [32] [33]. In our model, a decrease in RAR $\alpha$ expression was observed in the VAD group, whereas during the supplementation period, these levels reached similar values to the $\mathrm{CO}$ group. This situation would be suggesting that RAR $\alpha$ levels would be related to vitamin A concentration.

From the model of null mice in CRBP-1 this protein is proposed as a chaperone of retinoid metabolism [34]. The cytoplasmic concentration of CRBP-1 may determine the ability of the cell to accumulate retinol, and thus, serve as a cell regulator for its incorporation [35] [36]. CRBP-1 would be involved in the intermembrane movement of retinol, as well as in the metabolism of both retinyl esters (for storage) and retinal for subsequent activation or catabolism [37]. 
In vitro experiments show that retinoic acid can up-regulate CRBP-1 expression in adipocytes [38]. Hussmann et al. [39] observed that the expression of rat CRBP-1 can be upregulated by retinoic acid. In spleen, lung and testis of rats with 70 days of retinol deficiency, CRBP-1 mRNA decreased. In our results it was observed that the expression of CRBP-1 decreased in the VAD group, whereas in the REF group, the expression of CRBP-1 did not reach the level of the $\mathrm{CO}$ group. Our findings demonstrate the connection between CRBP-1 expression and retinoic acid levels. The 5 region flanking CRBP-1 gene is conserved between rat and mouse, and includes a RARE (retinoic acid response element) at $1 \mathrm{~kb}$ upstream of the start site of transcription. RARE is activated by RAR ( $\alpha$ and $\beta$ ), but not by RAR $\gamma 1$. On the other hand, RARE of CRBP-1 is most effectively activated when RAR and RXR are present. Induction of CRBP-1 transcription by retinoic acid is mediated by the binding of a RAR/RXR heterodimer with a RARE located in a specific promoter region [39].

The accumulation of CRBP-1 promotes the conversion of retinol to retinoic acid [40]. Ghyselinck et al., in a study of CRBP-1 null mice, demonstrated that CRBP-1 is essential for the efficient storage of retinol, but is not essential for retinoic acid synthesis [41]. Moreover, the downregulation of CRBP-1 has been associated with the malignant phenotype, especially in breast and ovarian cancer [29] [42] [43]. In $24 \%$ of human breast carcinomas, CRBP-1 expression is decreased; which implies a relationship between cellular homeostasis of vitamin A and breast cancer. The loss of CRBP-1 restricts the effects of endogenous vitamin A on neoplastic mammary gland cells. [29]. Esteller et al., in 2002, suggested that aberrant methylation of the promoter region may be one of the mechanisms underlying the silencing of CRBP-1 in tumor cell lines and in primary tumors [43]. Alterations in CRBP-1 expression and hypermethylation occur frequently in prostate carcinoma, although CRBP-1 hypermethylation is not an early event in this type of cancer [45].

The upregulation of homologous CRBP proteins (CRBP-2 and/or CRBP-3) contribute to the maintenance of the retinoid acid level in the absence of CRBP-1 [46] [47]. However, since CRBP-1 and its homologues normally have different functions, CRBP-2 and CRBP-3 don't restore the total functionality of CRBP-1 [47] [48]. In addition, loss of CRBP-1 is an early event in the progression of breast cancer and is associated with poor prognosis [29]. Loss of CRBP-1 disrupts retinoic acid homeostasis, resulting in breast defects similar to those observed in the early stages of tumorigenesis [49]. These data highlight the role of CRBP-1 as a regulator and also emphasize the essential role of retinoic acid in maintaining adequate breast morphology and the need for strict regulation of the active metabolite of vitamin A. The characterization of CRBP-1 phenotype will help with the development of novel therapeutic strategies for CRBP-1 deficient breast cancer.

A loss of CRBP-1 expression is also associated with the development of less differentiated endometrial carcinomas [50]. CRBP-1 hypermethylation is re- 
sponsible for the loss of transcription of CRBP-1 mRNA that takes place in premalignant lesions and frequently accompanied by $\operatorname{RAR} \beta 2$ hypermethylation in the same tumors. Moreover, it was observed that a higher dietary intake of retinol was associated with decreased methylation of both genes [43].

In recent years, the role of retinoid signaling along with CRBP-1 has become the subject of several studies in cancer progression. CRBP-1 suppression is associated with a more aggressive phenotype in breast, ovary, and nasopharyngeal cancer. Overexpression of CRBP-1 increases the sensitivity to retinol and reduces the viability of ovarian cancer cells in vitro [51].

Epidemiological studies have suggested an inverse correlation between cancer development and vitamin A consumption [52]. Natural and synthetic retinoids have been shown to inhibit the growth and development of different types of tumors; such as: skin, breast, oral cavity, lung, hepatic, gastrointestinal, prostate, and bladder cancers [53] [54].

\section{Conclusions}

For this reason, this animal model of virgin rats with 6 months of deficiency in vitamin A can be a study model to observe the different changes that this generates in a virgin mammary gland that despite being in the basal state already presents a deficiency in vitamin A. This gives an excellent field study to observe the metabolic processes such as tumor predisposition, inflammation, among others, where this vitamin is involved.

\section{Acknowledgements}

This work has been supported by CONICET (Consejo Nacional de Investigaciones Científicas y Tecnicas, Argentina), and 8104, Universidad Nacional de San Luis, Argentina. The authors are indebted to Carolina Ferrari and for their excellent technical assistance.

\section{Conflict of Interest}

No potential conflict of interest was disclosed.

\section{References}

[1] Who (2009) Global Prevalence of Vitamin A Deficiency in Populations at Risk 1995-2005. WHO Global Database on Vitamin A Deficiency. World Health Organization.

[2] Stevens, G.A., Bennett, J.E., Hennocq, Q., Lu, Y., De-Regil, L.M., Rogers, L., Danaei, G., Li, G., et al. (2015) Trends and Mortality Effects of Vitamin A Deficiency in Children in 138 Low-Income and Middle-Income Countries between 1991 and 2013: A Pooled Analysis of Population-Based Surveys. The Lancet Global Health, 3, E528-E536. https://doi.org/10.1016/S2214-109X(15)00039-X

[3] Abrha, T., Girma, Y., Haile, K., Hailu, M. and Hailemariam, M. (2016) Prevalence and Associated Factors of Clinical Manifestations of Vitamin A Deficiency among Preschool Children in Asgede-Tsimbla Rural District, North Ethiopia, a Community Based Cross Sectional Study. Archives of Public Health, 74, 4. 
https://doi.org/10.1186/s13690-016-0122-3

[4] Klemm, R., Palmer, A., Greig, A., Engle-Stone, R. and Dalmiya, N. (2016) A Changing Landscape for Vitamin A Programs: Implications for Optimal Intervention Packages, Program Monitoring, and Safety. Food and Nutrition Bulletin, 1-12. https://doi.org/10.1177/0379572116630481

[5] Stephensen, C.B. (2001) Vitamin A, Infection, and Immune Function. The Annual Review of Nutrition, 21, 167-192. https://doi.org/10.1146/annurev.nutr.21.1.167

[6] Ivan, P., Uray, M.D., Dmitrovsky, E., Powel, H. and Brown, M.D. (2016) Retinoids and Rexinoids in Cancer Prevention: From Laboratory to Clinic. Seminars in Oncology, 43, 49-64. https://doi.org/10.1053/j.seminoncol.2015.09.002

[7] Clagett-Dame, M. and Knutson, D. (2011) Vitamin A in Reproduction and Development. Nutrients, 3, 385-428. https://doi.org/10.3390/nu3040385

[8] Gudas, L.J. (2012) Emerging Roles for Retinoids in Regeneration and Differentiation in Normal and Disease States. Biochimica et Biophysica Acta, 1821, 213-221. https://doi.org/10.1016/j.bbalip.2011.08.002

[9] WHO/UNICEF (1994) Indicators for Assessing Vitamin A Deficiency and Their Application in Monitoring and Evaluating Intervention Programmes. Review Version.

[10] Tanumihardjo, S.A. (2011) Vitamin A: Biomarkers of Nutrition for Development. The American Journal of Clinical Nutrition, 94, 658S-665S. https://doi.org/10.3945/ajen.110.005777

[11] Figueroa, D., Dantas, A. and Sales, M.C. (2013) Micronutrientes Deficiencias y Lineal de Crecimiento: Una Revisión Sistemática de Estudios Observacionales. [Micronutrients Deficiencies and Linear Growth: A Systematic Review of Observational Studies.] Noticias de Salud de Rio de Janeiro, 11, 18.

[12] Cediel, G., Olivares, M., Lopez de Romana, D., La Frano, M., Brito, A. and Cori, H. (2015) Interpretation of Serum Retinol Data from Latin America and the Caribbean. Food and Nutrition Bulletin, 36, S98-S108. https://doi.org/10.1177/0379572115585743

[13] Dollé, P. and Niederreither, K. (2015) The Retinoids. Biology, Biochemistry, and Disease. Wiley Blackwell, United States of America. https://doi.org/10.1002/9781118628003

[14] Reeves, P.G. (1996) AIN-93 Purified Diets for the Study of Trace Element Metabolism in Rodents. Trace Elements in Laboratory Rodents Ed., Watson.

[15] Neeld, J.B. and Pearson, W.N. (1963) Macro- and Micro-Methods for the Determination of Serum Vitamin a Using Trifluoroacetic Acid. Journal of Nutrition, 79, 454-462.

[16] Puissant, C. and Houdebine, L.M. (1990) An Improvement of the Single-Step Method of RNA 29 Isolation by Acid Guanidinium Thiocyanate-Phenol-Chloroform Extraction. 30 Biotechniques, 8, 148-149.

[17] West, K.P., LeClerq, S.C., Shrestha, S.R., Wu, L.S., Pradhan, E.K., Khartry, S.K., Kats, J., Adhikari, R. and Sommer, A. (1997) Effects of Vitamin A on Growth of Vitamin Deficient Children. Field Studies in Nepal. Journal of Nutrition, 127, 1957-1965.

[18] Trasino, S.E., Tang, X.-H., Jessurun, J. and Gudas, L.J. (2015) Obesity Leads to Tissue, but not Serum Vitamin A Deficiency. Scientific Reports, 5, Article No. 15893. https://doi.org/10.1038/srep15893

[19] Berry, D.C. and Noy, N. (2009) All-Trans-Retinoic Acid Represses Obesity and In- 
sulin Resistance by Activating both Peroxisome Proliferation-Activated Receptor $\beta / \delta$ and Retinoic Acid Receptor. Molecular and Cellular Biology, 29, 3286-3296. https://doi.org/10.1128/MCB.01742-08

[20] Goodman, D.S. and Blaner, W.S. (1984) Biosynthesis, Absorption, and Hepatic Metabolism of Retinol. In: Sporn, M.B., Roberts, A.B. and Goodman, D.S., Eds., The Retinoids, Vol. 2, Academic Press, New York, 1-39.

[21] Vogel, S., Gamble, M.V. and Blaner, W.S. (2010) Retinoid Uptake, Metabolism and Transport. In: Nau, H. and Blaner, W.S., Eds., The Handbook of Experimental Pharmacology, The Retinoids, Springer Verlag, Heidelberg, 31-96.

[22] Ross, C. (2010) Diet in Vitamin A Research. Methods in Molecular Biology, 652, 1-17. https://doi.org/10.1007/978-1-60327-325-1_17

[23] Duester, G. (2008) Retinoic Acid Synthesis and Signaling during Early Organogenesis. Cell, 134, 921-931.

[24] Maden, M. and Hind, M. (2003) Retinoic Acid, a Regeneration-Inducing Molecule. Developmental Dynamics, 226, 237-244. https://doi.org/10.1002/dvdy.10222

[25] Noy, N. (2010) Between Death and Survival: Retinoic Acid in Regulation of Apoptosis. Annual Review of Nutrition, 30, 201-217. https://doi.org/10.1146/annurev.nutr.28.061807.155509

[26] Cho, K.W., Kwon, H.J., Shin, J.O., Lee, J.M., Cho, S.W., Tickle, C. and Jung, H.S. (2012) Retinoic Acid Signaling and the Initiation of Mammary Gland Development. Developmental Biology, 365, 259-266.

[27] Wolbach, S.B. and Howe, P.R. (1978) Tissue Changes Following Deprivation of Fat-Soluble A Vitamin. Nutrition Reviews, 36, 16-19. https://doi.org/10.1111/j.1753-4887.1978.tb03675.x

[28] Xu, G., Redard, M., Gabbiani, G. and Neuville, P. (1997) Cellular Retinol-Binding Protein-1 Is Transiently Expressed in Granulation Tissue Fibroblasts and Differentially Expressed in Fibroblasts Cultured from Different Organs. American Journal of Pathology, 15, 1741-1749.

[29] Kuppumbatti, Y.S., Bleiweiss, I.J., Mandeli, J.P., Waxman, S. and Mira, Y.L.R. (2000) Cellular Retinol-Binding Protein Expression and Breast Cancer. Journal of the National Cancer Institute, 92, 475-480. https://doi.org/10.1093/jnci/92.6.475

[30] Kim, K.H. and Griswold, M.D. (1990) The Regulation of Retinoic Acid Receptor mRNA Levels during Spermatogenesis. Molecular Endocrinology, 4, 1679-1688. https://doi.org/10.1210/mend-4-11-1679

[31] Haq, R., Pfahl, M. and Chytil, F. (1991) Retinoic Acid Affects the Expression of Nuclear Retinoic Acid Receptors in Tissues of Retinol-Deficient Rats. Proceedings of the National Academy of Sciences of the United States of America, 88, 8272-8276. https://doi.org/10.1073/pnas.88.18.8272

[32] Verma, A.K., Shoemaker, A., Simsiman, R., Denning, M. and Zachman, R.D. (1992) Expression of Retinoic Acid Nuclear Receptors and Tissue Transglutaminase Is Altered in Various Tissues of Rats Fed a Vitamin A-Deficient Diet. Journal of Nutrition, 122, 2144-2152.

[33] Hu, Z., Fujio, K., Marsden, E.R., Thorgeirsson, S.S. and Evarts, R.P. (1994) Hepatic Regeneration in Vitamin A-Deficient Rats: Changes in the Expression of Transforming Growth Factor Alpha/Epidermal Growth Factor Receptor and Retinoic Acid Receptors Alpha and Beta. Cell Growth \& Differentiation, 5, 503-508.

[34] Napoli, J.A. (2000) Gene Knockout Corroborates the Integral Function of Cellular Retinol-Binding Protein in Retinoid Metabolism. Nutrition Review, 58, 230-241. 
https://doi.org/10.1111/j.1753-4887.2000.tb01870.x

[35] Ross, A.C. (1993) Cellular Metabolism and Activation of Retinoids: Roles of Cellular Retinoid-Binding Proteins. The FASEB Journal, 7, 317-327.

[36] Ross, A.C. (1993) Overview of Retinoid Metabolism. Journal of Nutrition, 123, 346-350.

[37] Nagy, N.E., Holven, K.B., Roos, N., Senoo, H., Kojima, N., Norum, K.B. and Blomhoff, R. (1997) Storage of Vitamin A in Extrahepatic Stellate Cells in Normal Rats. The Journal of Lipid Research, 38, 645-658.

[38] D’Ambrosio, D.N., Clugston, R.D. and Blaner, W.S. (2011) Vitamin A Metabolism: An Update. Nutrients, 3, 63-103. https://doi.org/10.3390/nu3010063

[39] Hussmann, M., Hoffmann, B., Stump, G.D., Chytil, F. and Pfahl, M. (1992) A Retinoic Acid Response Element from the Rat CRBP-1 Promoter Is Activated by an RAR/RXR Heterodimer. Biochemical and Biophysical Research Communications, $187,1558-1564$

[40] Xu, G., Bochaton-Piallat, M.L., Andreutti, D., Low, R.B., Gabbiani, G. and Neuville, P. (2001) Regulation of a-Smooth Muscle Actin and CRBP-1 Expression by Retinoic Acid and TGF-b in Cultured Fibroblasts. Journal of Cellular Physiology, 187, 315-325. https://doi.org/10.1002/jcp.1078

[41] Ghyselinck, N.B., Bavik, C., Sapin, V., Mark, M., Bonnier, D., Hindelang, C., Dierich, A., Nilsson, C.B., Hakansson, H., Sauvant, P., Azais-Braesco, V., Frasson, M., Picaud, S. and Chambon, P. (1999) Cellular Retinol Binding Protein I Is Essential for Vitamin A Homeostasis. The EMBO Journal, 18, 4903-4914.

https://doi.org/10.1093/emboj/18.18.4903

[42] Kuppumbatti, Y.S., Rexer, B. and Nakajo, S. (2001) CRBP Suppresses Breast Cancer Cell Survival and Anchorage Independent Growth. Oncogene, 20, 7413-7419.

https://doi.org/10.1038/sj.onc.1204749

[43] Cvetković, D., Williams, S.J. and Hamilton, T.C. (2003) Loss of Cellular Retinol-Binding Protein 1 Gene Expression in Microdissected Human Ovarian Cancer. Clinical Cancer Research, 9, 1013-1020.

[44] Esteller, M., Guo, M., Moreno, V., Peinado, M.A., Capella, G., Galm, O., Baylin, S.B. and Herman, J.G. (2002) Hypermethylation-Associated Inactivation of the Cellular Retinol Binding Protein 1 Gene in Human Cancer. Cancer Research, 62, 5902-5905.

[45] Jerónimo, C., Henrique, R., Oliveira, J., et al. (2004) Aberrant Cellular Retinol Binding Protein 1 (CRBP1) Gene Expression and Promoter Methylation in Prostate Cancer. Journal of Clinical Pathology, 57, 872-876. https://doi.org/10.1136/jcp.2003.014555

[46] Piantedosi, R., Ghyselinck, N., Blaner, W.S. and Vogel, S. (2005) Cellular Retinol-Binding Protein Type III Is Needed for Retinoid Incorporation into Milk. The Journal of Biological Chemistry, 280, 24286-24292. https://doi.org/10.1074/jbc.M503906200

[47] Kane, M.A., Folias, A.E., Pingitore, A., Perri, M., Krois, C.R., Ryu, J.Y., Cione, E. and Napoli, J.L. (2011) Crbp1 Modulates Glucose Homeostasis and Pancreas 9-Cis-Retinoic Acid Concentrations. Molecular and Cellular Biology, 31, 3277-3285. https://doi.org/10.1128/MCB.05516-11

[48] Vogel, S., Mendelsohn, C.L., Mertz, J.R., Piantedosi, R., Waldburger, C., Gottesman, M.E. and Blaner, W.S. (2001) Characterization of a New Member of the Fatty Acid-Binding Protein Family that Binds All-Trans-Retinol. The Journal of Biological Chemistry, 276, 1353-1360. https://doi.org/10.1074/jbc.M005118200 
[49] Pierzchalski, K., Yu, J., Norman, V. and Kane, M.A. (2013) Crbp1 Regulates Mammary Retinoic Acid Homeostasis and the Mammary Microenvironment. The FASEB Journal, 27, 1904-1916. https://doi.org/10.1096/fj.12-219410

[50] Orlandi, A., Ferlosio, A., Ciucci, A., Francesconi, A., Lifschitz-Mercer, B., Gabbiani, G., Spagnoli, G. and Czernobilsky, B. (2006) Cellular Retinol Binding Protein-1 Expression in Endometrial Hyperplasia and Carcinoma: Diagnostic and Possible Therapeutic Implications. Modern Pathology, 19, 797-803.

[51] Doldo, E., Costanza, G., Ferlosio, A., Passeri, D., Bernardini, S., Scioli, M.G., Mazzaglia, D., Agostinelli, S., Del Bufalo, D., Czernobilsky, B. and Orlandi, A. (2014) CRBP-1 Expression in Ovarian Cancer: A Potential Therapeutic Target. Anticancer Research, 34, 3303-3312.

[52] Niles, R.M. (2004) Signaling Pathways in Retinoid Chemoprevention and Treatment of Cancer. Mutation Research, 555, 81-96.

[53] Altucci, L. and Gronemeyer, H. (2001) The Promise of Retinoids to Fight against Cancer. Nature Reviews Cancer, 1, 181-193. https://doi.org/10.1038/35106036

[54] Bryan, M., Pulte, E.D., Toomey, K.C., Pliner, L., Pavlick, A.C., Saunders, T. and Wieder, R.A. (2011) Pilot Phase II Trial of All-Trans Retinoic Acid (Vesanoid) and Paclitaxel (Taxol) in Patients with Recurrent or Metastatic Breast Cancer. Investigational New Drugs, 29, 1482-1487. https://doi.org/10.1007/s10637-010-9478-3

Submit or recommend next manuscript to OALib Journal and we will provide best service for you:

- Publication frequency: Monthly

- 9 subject areas of science, technology and medicine

- Fair and rigorous peer-review system

- Fast publication process

- Article promotion in various social networking sites (LinkedIn, Facebook, Twitter, etc.)

- Maximum dissemination of your research work

Submit Your Paper Online: Click Here to Submit

Or Contact service@oalib.com 